\title{
Marketing And Growth Strategies For Emerging Economies: A Case-Study Of Trinidad And Tobago
}

Rodney Oudan, Worcester State University, USA

Augustus N. Luparelli, Worcester State University, USA

\begin{abstract}
The intent of this study is to examine the marketing concepts and issues affecting economic development in Trinidad and Tobago as an emerging market. A careful review of literature, combined with the researcher's personal experience, produced this article demonstrating how marketing can assist economic development in the Trinidad and Tobago economy. The author draws mainly on personal experience and a theoretical framework to show the nature of business practice in Trinidad and Tobago and how changing economic factors have caused the economy to place some emphasis on marketing. This article highlights the benefits to be derived from changing from a production concept to marketing concept and a market-driven economy.
\end{abstract}

\begin{abstract}
Attention is given to three main sectors in the economy; namely, the government, multinational companies and indigenous marketers. The study outlines a marketing-oriented program undertaken by the government to promote economic development and incentives which are being offered to help stimulate marketing in the private sector. It indicates the extent of government involvement with multinationals and shows the advantages of this type of investment. The study concludes that marketing will have to play a much greater role in business activities, especially as an orientation for growth, innovation and future development.
\end{abstract}

Keywords: Global Marketing; Economic Development; Emerging Markets

\section{INTRODUCTION}

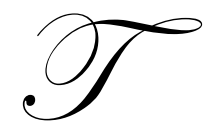

rinidad and Tobago is an emerging market seeking economic growth. The country is classified by the 1992 World Bank Statistics as having an upper middle income. Trinidad and Tobago is considered to be a developing nation with major opportunities for growth and development. It is seen as a country that concentrates on the production of raw materials for export. Much emphasis is placed on production of raw materials from natural resources. However, there have been many changes in recent years, including a downturn in the economy. The policies and strategies pursued to promote growth were effective only in the early years. Recent statistics show negative shifts in many areas, including national income, population, standards of living and market trends. In today's rapidly changing economic environment, increased emphasis has been placed on marketing management in advanced countries. Effective marketing will now become a challenge to this emerging market. Given a changing market environment and increasing demands of consumers, the need to address customer value and satisfaction is creating attention in Trinidad and Tobago. However, marketing professionals in this country must first understand the marketing concepts and strategies and its role in economic development to stimulate growth in the economy.

Marketing emphasizes innovation, needs, customer satisfaction and exchange. There has been much development in technology, communication and standards of living through marketing research in most advanced nations. Theorists, policy makers and practitioners believe that the role of marketing would therefore contribute significantly to the development of emerging markets. In this developing nation, marketing will allow the economy 
to use its resources in the most satisfactory way. In recent years, marketing has been given much attention in emerging countries; Kinsey (1988) argued "the need for more marketing in developing countries is being recognized as a means of helping minimize the effects of an increasing competitive international climate, production, plunging commodity prices, debt and numerous other difficulties that hamper economic growth."

Through marketing, unknown demand may be converted into opportunities in new product and services. This will create purchasing power and increase consumption and customer satisfaction. While broad general prescriptions have been made for the utilization of marketing in developing economies, Trinidad and Tobago's economy must be specifically addressed. Marketing is currently being practiced in some form, but a review needs to be made of how extensive or effective this practice is. In addition, specific areas and applications must be identified that would be most applicable in order to promote rapid economic development.

\section{METHODOLOGY}

Much has been written on the marketing concept. Extensive information is available in books and periodicals. However, there is not sufficient literature to support this specific area; that is, marketing in developing countries. To develop an in-depth understanding of marketing in the Trinidad and Tobago economy, a qualitative approach is pursued. In order to collect the necessary data for this study, emphasis was placed on secondary data printed statistics and articles obtained from Trinidad and Tobago government archives, periodicals and business journals, and primary data - an interview with the Trinidad and Tobago consulate in New York. A case study analysis was done using the researcher's personal working knowledge of the economy.

The study uses macro-marketing theories, such as the role of marketing as an engine of economic development. There are theorists, for example, who see marketing as a progenitor of growth. Drucker (1958) and Bartels (1981) emphasized that until more concepts and theories are developed and more empirical research undertaken, the debate of marketing in developing countries will continue. Quantitative methods were not used in accessing this information because of the nature of data collection.

The data that was collected for this study reflects current thinking regarding the issues on marketing in emerging markets. It conveys the working knowledge of the researcher and supports the opinions of scholars and professionals in this field. Based on the analysis of this data, conclusions were reached regarding the importance and the necessity of the modern marketing concept for national development.

\section{THE STUDY}

Marketing may be seen as the coordination of resources and activities directed at satisfying customer needs and wants. The marketing concept has been broadly defined by Kotler in 2000. Marketing is the business function that identifies unfulfilled needs and wants, defines and measures their magnitude, determines which target market the organization can best serve, decides on the appropriate products, services and programs to serve these markets, and calls upon everyone to think of and serve the customer. From a societal point of view, marketing is the link between a society's material requirements and its economic patterns of response (Kotler, 2000). Kotler's definition clearly implies that the customer is the foundation of all marketing activities. Most discussions of marketing focus on the role and importance of marketing with respect to manufacturing and service organizations.

Few authors have examined the implications which marketing may have for economic development. Most developing nations' policies on economic development have concentrated on the importance of production and consumption, seemingly neglecting the role which marketing must play if increased production and consumption are to have a maximum effect on the economy. This was realized by Kotler in 1984. He pointed out the importance of marketing objectives affecting economic development. However, he concentrated more on the function of consumption and its role in development. Miller (1967) stated that it is the nature of consumption to develop indefinitely, if permitted. Therefore, a society today that consumes mainly bread will develop more complex foods in the future if these new products are introduced properly. As consumption thus develops into more complex stages, so too will society, resulting in a more economically developed society (Kotler, 1984, and Miller, 1967). 
In economic development, marketing must play a major role in providing information to both consumer and producer. It is also useful in providing a network or system of effective channels of distribution to allow the flow of products to the consumer. Another area of importance in the concept of marketing is that of change and innovation. This is one area where marketing will contribute significantly since in developing nations, change is important to economic growth.

In earlier times, the economy of Trinidad and Tobago considered marketing a relatively unimportant activity. As long as manufacturers could sell what they produced and were protected from outside competition, the emphasis was on production. Modern thinking about economics has changed this model. Kinsey (1988) states, "There is no role for marketing, nor is there one made for economic development; but the two are inextricably linked. Marketing can act as a stimulus or pull factor in the economic development process." The author argues that effective management is required to bring forth and combine resources and capabilities. It is said that marketing can also act as a response factor in the development process. Lastly, marketing can also act as both a response and stimulus factor within the same economy. The author also points out that marketing might lag behind economic development until a certain point is reached after which marketing leads economic growth (Kinsey, 1988).

The strategy used to promote growth in Trinidad and Tobago was mostly the production concept, with little emphasis on marketing. The government made large investments in industrialization policy to facilitate the main production sectors in the economy. The emphasis was on manufacturing, and to support that emphasis, tariffs were imposed where necessary. This was done to protect local manufacturers from outside competition, thereby encouraging industrialization and development. The main area in the public sector was therefore the production of raw materials for protected overseas markets. This removed the perceived need for sound marketing principles. Marketing emerged as an important function only after the establishment of multinational corporations and after technical progress was made by regional manufacturers and markets. In addition, the present economic downturn and massive slowdown in economic growth has forced local manufacturers and government to begin to come to grips with what marketing is all about.

In 2000, Kinsey and Kotler each presented similar views on the marketing concept's importance to economic development. Kinsey argued that despite the fact that the marketing concept evolved in the advanced world and the boundaries of marketing have broadened considerably, in its widest sense the marketing function remains to serve and satisfy human needs and wants. By doing this, it may be considered to be a strategic element in the structure of any society since it directly allocates resources and has an important impact on other aspects of economic and social life. Consequently, its relevance to economic development is clear (Kinsey, 1988).

The 2002 Review of the Economy, published by the Trinidad and Tobago government, clearly demonstrates the need for more marketing research. The Review indicates that there were positive signs of a downturn in the economy resulting from slow trade. As stated in the Review, although production trends in some key sectors turned upwards, the economic environment continued to decline. This indicates that there was a surplus of goods that were not properly marketed. Further investigation has shown that many firms started business without knowledge about the needs, wants and preferences of their consumers. Apart from larger organizations in the country, systematic scientific research is minimal.

The researchers, who has six years of international marketing experience in this market and 14 years of international sales, have drawn conclusions about the uses of marketing research in this economy. Some weaknesses of business practices in this area are: 1) production programs were very often determined without knowledge of the size of the market, 2) information about distribution channels, sales forecasting and advertising were minimal, 3) competitive situations were usually limited, and 4) many decisions on marketing were based on assumptions about the market. These deficiencies are not confined only to the business sector, however. Although the government has organizations in place to conduct research in agriculture and other resource areas, little support is given to local manufacturers. Loan agencies and government institutions often permit applications for capital investments with minimal research. Certainly, if business is to fully appreciate the importance of market research, those agencies which service these businesses must themselves exhibit a greater tendency to collect meaningful market statistics. 
Several factors explain the low level of research activity in the country. First is the cost of meaningful market research, which is difficult for most local businessmen to afford. However, recognition of the value of good research and how it can influence decisions stimulate demand and create customer satisfaction and shows that research is a worthwhile investment. The second factor is the lack of marketing expertise to guide manufacturers. Much of the market research that is done utilizes government statistics and reports. These are normally published quarterly, and the information may be outdated by the time manufacturers and other organizations are ready to use it. In addition, these reports give aggregate information about imports, exports and trade and tell nothing about consumers' needs, attitudes and preferences - factors which are crucial for marketing decisions. The emphasis in government reports is basically on trade. At this point it is important to make a clear distinction between trade and marketing. Miracle and Albaum (1970) wrote, "Trade is the exchange or sale and purchase of goods. Thus, to trade is to transact and the volume of transactions is the volume of trade. But marketing is the aggregate activities or functions performed to make trade possible or desirable. Marketing activities facilitate the exchange of goods between producer and user."

Also, greater market awareness is needed to promote more creative product development. It must be remembered that marketing research creates a foundation through which customer satisfaction and national development can be achieved. There are 11 advertising corporations in Trinidad and Tobago, of which six have international affiliations. However, the development of an advertising campaign ought to be developed with specific objectives; such objectives would need proper market information for media and message selection. Thus there is clearly a need for careful planning and research among local businesses.

Many authors have provided examples of government involvement with marketing in emerging markets. Slater (1965), Kaynak (1982), Pandya (1985) and Kinsey (1988) have all agreed that improving marketing practice starts with making public policy decisions. This will help introduce existing technology from advanced nations, increase investments in market support facilities, and improve the infrastructure by building roads, transportation and storage facilities. Kinsey (1988) points out that marketing by the government is generally poor or limited in many developing countries. However, she stated, "It has a fundamental role to play, because the government intervenes to much a greater extent than in developed countries." The author also states that in order for a country's resources to be optimally used, marketing must be effectively understood and applied. Kaynak (1982) indicates that while many reasons exist for the lack of attention in marketing, including assumptions that marketing is parasitic, or will naturally evolve to the most efficient structure, there is ample evidence to suggest that planners do not know how best to use marketing activities to promote development. Therefore, the neglect by government planners may not be due so much to lack of concern about the role of marketing as due to their lack of knowledge of how best to use marketing policies.

These authors suggest that government involvement with marketing can be important to improving the economic development of a developing country. As we will see later on, this need for greater marketing to promote economic development is expected to play a major role in shaping the economic policies of such an economy. However, as noted earlier, the Trinidad and Tobago government minimized the need for scientific marketing principles. The economy was seen as one that concentrated on the production of available raw materials; namely, petroleum and agriculture, which gave the country a comparative advantage. The economy's prosperity was historically based on the production-driven strategy of resources, primarily crude oil and petroleum chemicals for protected overseas markets. This economic structure allowed the economy to thrive along with other oil-producing developing countries.

Another traditional approach by this government is its policy of central planning and ownership in all the utility sectors of the economy; for example, electricity, waterworks, communication, transportation and housing. Government therefore has a central role in economic and marketing decisions for national development. However, changing world economic conditions exposed the weaknesses in the central planning and government control as a primary element of economic development. Since 1984, there have been positive signs that the continuing decline in the economy was being arrested. These developments took place against the background of the continuing dependence in petroleum output (Trinidad and Tobago Government, 2003). 
The Trinidad and Tobago government is presently in the process of restructuring its economic policies and initiating market driven to promote development. The nation's historic emphasis on oil, petrochemicals and agriculture is now changing as the government introduces several marketing incentives as drivers for growth to improve the economy and move in the direction of economic development. Among these are economic, fiscal policies to encourage foreign direct investment to stabilize the economy and provide incentives for potential resource areas in the non-oil sector of the economy. In 1987, the Ministry of Industry, Commerce and Planning outlined principles to promote a mixed economy as an appropriate framework upon which the development of the country can be based. The plan was called an Investment Promotion Marketing Program, to provide for the following: 1) to promote export marketing in the non-oil sector of the economy, 2) to encourage private entrepreneurship, 3) to allow privatization of public corporations, thereby allowing for growth and distribution of ownership among citizens, and 4) to promote foreign capital investment in point venture arrangement (Trinidad and Tobago Industrial Development Corporation, 2005).

Recent developments indicate that the growth of multinationals in Trinidad and Tobago has been overwhelming. The government sees this growth as an indispensable means of assisting economic development. The government encourages multinationals to locate and do business in the country, provided they bring expertise, training, new technology and access to exports markets. It does, however, insist that multinationals organize and structure their local business in such a manner so that they will progressively replace all foreign resources, both financial and human, by local resources. The largest multinational organizations in the country are: Nestlé, Lever Brothers, Johnson and Johnson, Coca Cola, IBM, Texaco, Shell and similar corporations. These multinationals can be characterized by extremely effective marketing strategies. The organizational structure of these corporations exhibits a marketing orientation, making full use of scientific marketing principles. The use of the marketing mix models (price, place, promotion, and product) is effectively organized to develop marketing strategies. Products are marketed in such a manner so that they are not only perceived as being high-quality but also essential to the users' lives.

Kaynak (1982) commented on the effectiveness of multinationals, stating their importance and relevance to developing countries. He indicated that most developing nations see multinationals as reducing the cost of imports and improving the standard of living. Kinsey (1988) referred to the injection of multinationals in the last 30 years as being unprecedented. She indicated that products marketed in developed countries are considered suitable for new markets elsewhere, notably in developing countries, by using effective marketing strategies to target markets.

The above findings show that the Trinidad and Tobago government supports multinational investments because it is believed they can stimulate economic development.

With the exception of utilities, agriculture and oil industries, the major part of the Trinidad and Tobago economy is privately held. The private sector in this economy is comprised of local manufacturers, wholesalers and retailers. As mentioned earlier, there is a lack of marketing expertise and finance to stimulate a marketing orientation in the private sector. We saw earlier that for marketing to be effective, an understanding of the concepts is needed to create, build and maintain beneficial relationships with target markets (Kotler, 1984). Most of these local organizations would not be considered marketers. However, that depends on whether or not they understand and apply marketing activities effectively.

In manufacturing organizations, we saw that they were production-oriented with little use for marketing. Wholesalers and retailers also operated with a strong emphasis on selling rather than on long-term marketing strategy. This section examines the increase in awareness of marketing by the government and the relevance of the private sector to economic development. The government, bearing in mind the limited marketing in such firms, is now offering incentives to promote this sector of the economy.

However, it is clear that these organizations are not structured to undertake such a task. Marketing involves the monitoring of markets and marketing activities on a continuing basis. If market information is to be collected, analyzed and disseminated in a meaningful way, firms must be properly organized; that is, with proper marketing, training and expertise. In Trinidad and Tobago, not only was it clear that local manufacturers, wholesalers and retailers showed little evidence of sound marketing principles, but the sole objective was to make a profit, with little 
consideration for the consumer. Also, distribution, pricing and product policies were developed by management in these organizations, with little consideration of market factors, such as size of market or consumer preferences. These companies must understand that the marketing concept recognizes consumers' needs and wants and is the starting point for product and market planning. Failure of businesses to recognize this will be harmful to the whole economy.

The relationship of marketing to economic development suggests that marketing activities help stimulate demand. This results in increased production and consumption, which is what economic development is all about. The importance of marketing to Trinidad and Tobago has been recognized by government and businesses alike. Although it is still in its infant stages, there appears to be no questioning that as long as production surpasses effective demand, the nation's economic development depends upon marketing expertise to create new markets and increase consumption.

It is suggested that the economy should pay more attention to how marketing can assist in its development. Also, the greater utilization of broad marketing concepts, with emphasis on identifying consumer needs and wants and adjustment to varying demand conditions, will help create the orientation needed for development in this economy. However, companies must implement new policies to encourage growing productive capabilities. The implementation of sound marketing practices will ensure that this challenge is met. Historically, there is evidence that production and selling concepts have been used in Trinidad and Tobago. It was not, however, until a rapid slowdown in economic growth that marketing started gaining attention. The need for economic rejuvenation has therefore awakened the need for marketing development. Also, with changes in technology, the need for effective marketing to keep up-to-date has become crucial. This attention to marketing has created changes in public policy decisions; for example, in the field of external orientation (exports and foreign investment).

With these changes in business practice and a greater market emphasis, marketing must now play a constructive role and address several development issues such as consumer needs and wants, market demand supply and the utilization of resources in all sectors of the economy. The success of modern marketing concepts and strategies depends on providing an organizational structure to focus on customer satisfaction and related marketing functions. Such structures may include the implementation of a research and development department and marketing department or consultant to tailor and support marketing activities in channeling products and services to final consumers.

The economy's changing emphasis must also include meaningful marketing research. This is the most important function in the process. It involves the analysis of needs and wants and the identification of market trends. The result of this function is to apply knowledge to assist in decision-making and also to provide a framework for long-range planning and plotting future courses of action.

The government, which has the official role of central planning, has recognized the importance of marketing to the national economy. In the past three years, there have been increased efforts by the government to use marketing in economic planning for the development of the country. Marketing is being used to assess the country's resources and in the development of an overall plan on how best to use them. The introduction of the Export Promotion Program is being implemented to stimulate broader marketing activities within the economy. A similar application will be beneficial to agricultural planning for improvement in its fundamental areas, such as technology and distribution management. The structure of efficient marketing in the agricultural sector exists in the form of the Central Marketing Agency, but planners must still change their traditional approach and concentrate on market development strategies.

It was noted that there are few indigenous marketers in the economy, if a marketer is defined as someone who understands and applies marketing in order to create, build and maintain beneficial relationships with target markets. Conditions, such as poor distribution, lack of marketing expertise and finance, were the main reasons for limited marketing practice by local manufacturers, wholesalers and retailers. The development of new products has been affected by the lack of research and capital. Other problems have included quality control and communication. Also, most of these individual businesses are family-oriented without any formal structure for marketing. However, with the growing acceptance of marketing, government is looking at the private sector as a main source on which the 
development of the economy can be based. It recognizes that growth in the private sector is essential to the development process and is now restructuring its economic policies to allow incentives as a base for widening the private sector. For this to be effective and for long-run development, there needs to be a change in business orientation as the first step to scientific marketing.

\section{SUMMARY AND CONCLUSIONS}

This study has clearly indicated the need for scientific marketing in the national economy of Trinidad and Tobago as an emerging economy. Although a total marketing orientation seems nonexistent, there has been some acceptance and adoption of the marketing concept. This has resulted in the emergence of changes in public policy that emphasize marketing implications. It is also clear that there is lack of sensitivity to markets; sustained development demands a change in this practice. The business environment in Trinidad and Tobago is changing rapidly, and the economy must recognize this for future growth. A modern marketing orientation calls for changes in business practices, policy, organizational structure and, for the private sector, to play a more aggressive role. Recent advances in technology and business techniques will help encourage this type of development and application to better meet the challenge. Economic development will depend on how effectively the economy can implement these changes while using all available resources to create an environment that will promote innovation and development.

Specific considerations include: 1) the acceptance and commitment to a market orientation will be important to the success and development of the economy in the future, 2) marketing research will play an increasingly important role in development of marketing programs in all sectors of the economy, 3) considering the economic structure of this nation, marketing and public policy must guide investment and business activity accordingly, and 4) the world economic environment and patterns of doing business are changing; the Trinidad and Tobago economy must recognize and adapt to these changes in the marketing of products. Finally, the growing acceptance of marketing among emerging economies is an absolute necessity to greater efficiency and economic development.

\section{AUTHOR INFORMATION}

Dr. Rodney Oudan is an Associate Professor of Marketing at Worcester State University where he teaches International Marketing and Marketing Management. He has twelve years international marketing experience as a Brand Manager for Nestle Food Corporation. He earned his Doctorate in Business Administration with a concentration in Marketing from Nova Southeastern University and graduate degree in Management from Cambridge College. E-mail: roudan@worcester.edu

Dr. Gus Luprelli is a Professor of Management at Worcester State University where he teaches Management, Strategy and Policy. He has twenty years experience in global sales management. He earned his Doctorate from the University of Connecticut and graduate degree in management from Worcester State College. E-mail: gnluparelli@msn.com

\section{REFERENCES}

1. Alexander, A. (1960). A glossary of marketing terms. Chicago: American Marketing Association.

2. $\quad$ Baker, M. J. (1985a). Marketing: an introductory text. London: Macmillan.

3. Baker, M. J. (1985b). Marketing and advertising. London: Macmillan.

4. Ball, A. D. (1988). International business: introduction and essentials. ( $3^{\text {rd }}$ ed.). Englewood Cliffs, N.J.:1.

5. Carter, S. (1988). Multinational marketing in constraint economics. Institute of Marketing Journal, 13, 4.

6. Drucker, P. (1958). Marketing and economic development. Journal of Marketing, 22(3).

7. Economic Review of Trinidad and Tobago. (1998). Quarterly Economic Bulletin, 14. Port-of-Spain, Trinidad: Central Bank Office.

8. Kaynak, E. (1982). Marketing in the third world. New York: Praeger.

9. Kinsey, J. (1988). Marketing in developing countries. London: Macmillan. 
10. Kotler, P. (1984). Marketing management, analysis, planning and control. (4 ${ }^{\text {th }}$ ed.). Englewood Cliffs, N.J.: Prentice Hall.

11. Kotler, P. (2000). Marketing management, analysis, planning and control. (6 ${ }^{\text {th }}$ ed.). Englewood Cliffs, N.J.: Prentice Hall.

12. Miller, J. C. (1967). Marketing and economic development. Lincoln: University of Nebraska Press.

13. Miracle, E. \& Albaum. (1970). International marketing management. Homewood, Ill.: Irwin.

14. Pandya, A. (1985). Marketing and economic development. In Rethinking marketing's role in development. Boston: Northeastern University Press.

15. Price Waterhouse. (2004). Business Information of Trinidad and Tobago. New York: Center of Transnational Taxation.

16. Trinidad and Tobago Government. (2005). Review of the economy. Port-of-Spain, Trinidad: Central Statistical Office.

17. Trade Development Association. (2002). Trading statistics. Port-of-Spain, Trinidad: Central Statistical Office.

18. Slater, C. (1965). The role of marketing in economic development. Chicago: American Marketing Association.

19. Trinidad and Tobago Government. (2003). Review of the economy. Port-of-Spain, Trinidad: Central Statistical Office. 